\title{
JPCS
}

Peqguruang: Conference

Series

Vol. 3 No. 2 Nov. 2021

elSSN: 2686-3472

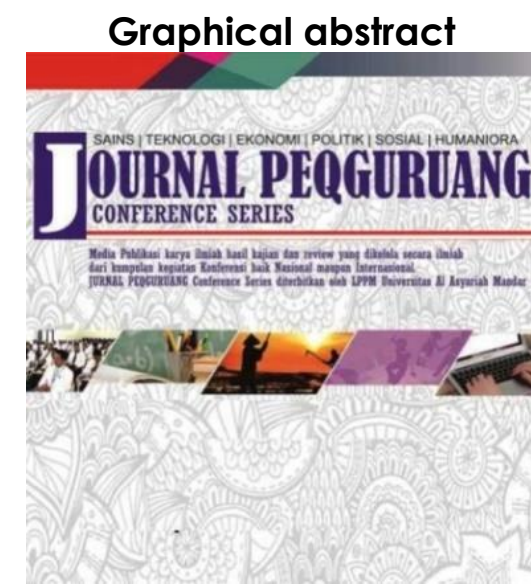

\section{KUALITAS PELAYANAN PEGAWAI PADA KANTOR KECAMATAN MAMASA KABUPATEN MAMASA}

\author{
${ }^{1 *}$ Yulianus, ${ }^{2}$ Abdul Khalik, ${ }^{3}$ Muh. Abid Alimuddin Lidda. \\ ${ }^{1}$ Ilmu Pemerinahan, ${ }^{2}$ Fakultas Ilmu- ilmu Sosial dan Ilmu \\ Pemerintahan, ${ }^{3}$ Universitas Al Asyariah Mandar
}

Corresponding author:

yulianustadibali@gmail.com

\begin{abstract}
This study aims to determine the quality of public services at the Mamasa District Office, Mamasa Regency. This study uses descriptive qualitative research methods that describe and describe events and phenomena that occur in the field and present data in a systematic, factual, and accurate manner. Data was collected by using observation, interview, and documentation techniques. Researchers used source triangulation to check the validity of research data. Data analysis in this study uses three components consisting of data reduction, data presentation, and drawing conclusions. The results of this study indicate that the quality of public services at the Mamasa District Office, Mamasa Regency has implemented the dimensions of Physical Evidence/ Tangibility, Reliability, Responsiveness, Assurance, Empathy along with its indicators in providing services. However, there are still several indicators that have not been implemented in accordance with the wishes of the community, including the inconvenience of the service place including incomplete facilities and infrastructure, not all employees are capable and skilled in using service aids, and unfriendly staff in the service process, slow processing time uncertain or long and there are employees who prioritize personal interests over public interests and discriminate in providing services.
\end{abstract}

Keywords: Quality of Public Services, public services

\section{Abstrak}

Penelitian ini bertujuan untuk mengetahui kualitas pelayanan publik di Kantor Kecamatan Mamasa Kabupaten Mamasa. Penelitian ini menggunakan metode penelitian deskriptif kualitatif yang menggambarkan dan mendeskripsikan peristiwa maupun fenomena yang terjadi di lapangan dan menyajikan data secara sistematis, faktual, dan akurat. Pengumpulan data dilakukan dengan teknik observasi, wawancara, dan dokumentasi. Peneliti menggunakan triangulasi sumber untuk mengecek keabsahan data penelitian. Analisis data dalam penelitian ini menggunakan tiga komponen yang terdiri dari reduksi data, penyajian data, dan penarikan kesimpulan. Hasil penelitian ini menunjukan bahwa Kualitas pelayanan publik di Kantor Kecamatan Mamasa Kabupaten Mamasa sudah menerapkan dimensi Fisik/wujud, Kehandalan, Daya Tanggap, Jaminan, Empati beserta indikatornya dalam memberikan Pelayanan sudah berjalan baik. Namun masih ada beberapa dimensi yang belum berjalan sesuai dengan keinginan masyarakat, antara lain ketidak nyamanan tempat pelayanan termasuk sarana dan prasarana yang belum lengkap, belum semua pegawai mampu dan ahlinya dalam menggunakan alat bantu pelayanan, dan ketidak ramahan pegawai dalam proses pelayanan, waktu proses yang tidak pasti atau lama dan adanya pegawai yang mendahulukan kepentingan pribadi daripada kepentingan umum serta membeda-bedakan dalam memberikan pelayanan.

Kata Kunci : Kualitas, Pelayanan Publik, Pegawai

\section{Article history}

DOI: https://dx.doi.org/10.35329/jp.v3i2.2227

Received : 05 September 2021 | Received in revised form : 12 Oktober 2021 | Accepted : 21 Novemeber 2021 


\section{PENDAHULUAN}

Kualitas pelayanan publik yang diberikan kepada masyarakat merupakan salah satu indikator yang menentukan kepuasan masyarakat terhadap apa yang diberikan oleh instansi tersebut. Jika kualitas pelayanan yang diberikan kepada masyarakat baik, maka akan membuat masyarakat pengguna jasa beranggapan instansi telah profesional dalam memberikan pelayanannya. Begitu pula sebaliknya jika masyarakat beranggapan kualitas pelayanan yang diberikan buruk, maka masyarakat akan beranggapan kalau instansi kurang profesional dalam memberikan layanan kepada masyarakat. Ada beberapa faktor penentu kepuasan pelanggan salah satunya adalah persepsi pelanggan terhadap kualitas pelayanan jasa, dimana tingkat kepuasan pelanggan adalah tingkat perasaan dimana seseorang yang menyatakan hasil perbandingan antara kinerja pelayanan yang diterima dengan yang diharapkan. Berdasarkan kondisi tersebut dapat dipahami bahwa kepuasan masyarakat dapat dipengaruhi oleh tingkat kualitas pelayanan yang diberikan pegawai, sedangkan pelayanan publik dapat mempengaruhi kepuasan masyarakat.

Menurut Peraturan Menteri Pendayagunaan Aparatur Negara Dan Reformasi Birokrasi Republik Indonesia Nomor 15 Tahun 2014, komponen standar pelayanan yang terkait dengan proses penyampaian pelayanan meliputi Persyaratan, prosedur, jangka waktu pelayanan, biaya/tarif, produk pelayanan, dan penanganan pengaduan. Jika suatu Instansi pemerintah dan lembaga lainnya mampu menerapkan standar kualitas tersebut maka sudah dapat dikatakan bahwa Instansi pemerintah dan lembaga tersebut telah memberikan kualitas pelayanan yang baik.

Pencapaian peningkatan bantuan normal di bidang bantuan publik, khususnya administrasi yang berwenang, tidak dapat dipisahkan dari pameran otoritas pemerintah. Untuk memahami peningkatan administrasi implementasi kebijakan, penting untuk memiliki faktor tekad yang muncul dan mengisi pekerja. Dengan inspirasi kerja yang tinggi, sebenarnya Anda akan ingin memberikan energi yang menggerakkan segala potensi yang ada, membuat ngidam yang tinggi dan terhormat, serta menambah silaturahmi (Nurfitrah, 2019)

Kantor Kecamatan Mamasa Kabupaten Mamasa merupakan salah satu contoh instansi yang harus memberikan pelayanan kepada masyarakat yang membutuhkan kelengkapan administrasi, surat-surat dan sebagainya. Kantor Kecamatan Mamasa Kabupaten Mamasa sebagai instansi pemerintah yang bertugas memberikan pelayanan umum senantiasa dituntut untuk bekerja secara optimal dam melayani masyarakat.

Namun kenyataannya, pelayanan publik yang diselenggarakan oleh Kantor Kecamatan Mamasa belum memenuhi kualitas yang diharapkan masyarakat. Hal ini ditandai dengan masih adanya berbagai keluhan masyarakat mengenai pelayanan. Sebagai contoh adanya masyarakat yang kesulitan ketika mengurus dokumen seperti KTP (Kartu Tanda Penduduk), KK (Kartu Keluarga), Akta Kelahiran, Akta Kematian dan surat surat lainnya, keluhan masyarakat yang tidak ditanggapi dengan cepat, adanya pegawai yang mendahulukan kepentingan pribadi dari pada umum, serta membeda bedakan dalam memberikan pelayanan.

Menurut Abdullah (2014: 2) Pegawai/ karyawan adalah sumber daya manusia/ penduduk yang bekerja disuatu institusi baik pemerintah maupun swasta (bisnis). Sementara Wirawan (2015: 17) mengatakan bahwa sumber daya manusia merupakan sumberdaya yang digunakan untuk menggerakkan dan mensiergikan sumberdaya lain untuk mencapai tujuan organisasi.

Menurut Kamus Besar Bahasa Indonesia (2012: 394) menjelaskan bahwa pelayanan merupakan perihal atau cara melayani, usaha melayani kebutuhan orang lain dengan memperoleh imbalan (uang), jasa serta kemudahan yang diberikan sehubungan dengan jual beli barang atau jasa. Adapun menurut Moenir (2015: 16-17) menjelaskan bahwa pelayanan merupakan suatu proses pemenuhan kebutuhan melalui aktifitas orang lain yang langsung. Sedangkan menurut Daryanto dan Setyobudi (2014: 122) menjelaskan bahwa pelayanan merupakan suatu proses yang menghasilkan suatu produk yang berupa pelayanan, kemudian diberikan kepada pelanggan.

Pelayanan publik merupakan salah satu kebutuhan dalam rangka pemenuhan pelayanan sesuai peraturan perundang-undangan. Pemenuhan kebutuhan merupakan hak dasar bagi setiap warga negara dan penduduk untuk mendapatkan pelayanan atas barang, jasa dan administratif yang disediakan oleh penyelenggara pelayanan publik dengan maksimal.

Sementara menurut Hardiyansyah (2011: 12) pengertian pelayanan publik adalah melayani keperluan orang atau masyarakat atau organisasi yang memiliki kepentingan pada organisasi, sesuai dengan aturan pokok dan tata cara yang ditentukan dan ditujukan untuk memberikan kepuasan kepada penerima layanan.

Berdasarkan uraian tersebut di atas dapat dirumuskan suatu permasalahan sebagai berikut : "Bagaimanakah kualitas pelayanan Pegawai pada Kantor Kecamatan Mamasa Kabupaten Mamasa”?

Tujuan yang ingin dicapai dalam penelitian ini adalah: "Untuk mengetahui kualitas pelayanan pegawai pada Kantor Kecamatan Mamasa Kabupaten Mamasa".

Penelitian ini diharapkan mampu memberikan manfaat sebagai berikut:

1. Sebagai bahan referensi bagi yang berminat untuk memperdalam masalah kualitas pegawai dalam memberikan pelayanan publik.

2. Bagi penulis, sebagai syarat menyelesaikan pendidikan dan memperoleh gelar sarjana ilmu pemerintahan di Universitas Al Asyariah Mandar.

3. Penelitian ini diharapkan dapat memberikan masukan yang berguna bagi peneliti lain untuk dapat berfikir secara analisis dan dinamis di masa yang akan datang.

\section{Kerangka Pemikiran}

Kualitas pelayanan yang diberikan oleh pegawai akan mempengaruhi sikap dari masyarakat yang dilayaninya. Sikap tersebut terwujud dalam bentuk puas atau ketidakpuasan masyarakat terhadap pelayanan pegawai. Apabila kualitas pelayanan yang 
diberikan sangat buruk maka masyarakat akan merasa sangat tidak puas, sebaliknya jika kualitas pelayanan yang diberikan sangat baik maka masyarakat akan merasa sangat puas. Masyarakat akan membandingkan antara tingkat kinerja yang dirasakan dengan tingkat harapan yang diinginkan. Apabila tingkat kinerja yang dirasakan melebihi tingkat harapan yang diinginkan, maka masyarakat cenderung merasa puas.

Untuk mengukur secara operasional kualitas pelayanan pegawai terhadap kepuasan masyarakat di Kantor Kecamatan Mamasa dapat dipergunakan indikator-indikator sebagai berikut:

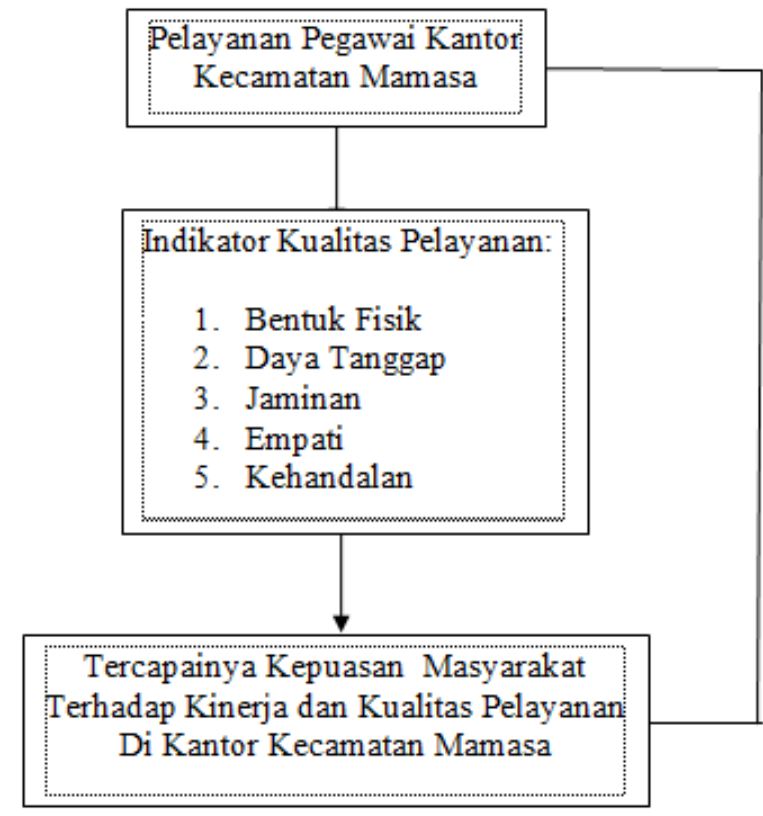

Gambar 1. Kerangka Pemikiran

\section{METODE PENELITIAN}

\section{MetodePenelitian}

Jenis penelitian ini adalah kualitatif yang mempunyai sifat deskriptip dengan memberikan gambaran terhadap keadaan nyata yang ada di masyarakat atau lingkungan masyarakat dengan maksud dan tujuan untuk menemukan fakta (factfinding), yang kemudian menuju pada identifikasi (problem-identification) dan pada akhirnya menuju kepada penyelesaian masalah (problem-solution).

Penelitian kualitatif adalah penelitian yang bermaksud untuk memahami fenomena tentang apa yang dialami oleh subjek penelitian misalnya prilaku, perinsip, motivasi tindakan, secara holistik dan dengan cara deskriptif dalam bentuk kata-kata dan bahasa, pada suatu konteks khusus yang alamiah dan dengan memanfaatkan berbagai metode ilmiah (Agusnadi, 2014). Pendekatan deskriptif bertujuan membuat deskripsi secara sistematis, faktual dan akurat tentang fakta-fakta dan sifat-sifat populasi atau objek tertentu (HERIAWAN, 2016).

\section{Waktu Dan Tempat}

Penelitian ini dilaksanakan di Kantor Dinas Perhubungan Kabupaten Mamasa, yang berlangsung pada bulan Febuari sampai Maret 2021.
Tabel 1. Tabel Penelitian

\begin{tabular}{|l|l|l|l|l|l|l|l|}
\hline No & Nama Kegiatan & Des & Jan & Feb & Mar & Apr & Mei \\
\hline 1 & Pengajuan Judul & & & & & & \\
\hline 2 & Penyusunan Proposal & & & & & & \\
\hline 3 & Proposal & & & & & & \\
\hline 4 & $\begin{array}{l}\text { Observasi, } \\
\text { Wawancara, } \\
\text { Dokumentasi }\end{array}$ & & & & & & \\
\hline 5 & $\begin{array}{l}\text { Pengumpulan Data } \\
\text { dan Analisis Data }\end{array}$ & & & & & & \\
\hline 6 & Penyusunan & & & & & & \\
\hline
\end{tabular}

\section{Informan Penelitian}

Teknik sampling yang digunakan dalam penelitian ini adalah purposive sampling yaitu teknik penentuan sampel dengan pertimbangan tertentu. Subyek yang dipilih menjadi sampel sesuai dengan ciri-ciri khusus yang dimiliki sampel. Menurut (Amirullah, 2015) Purposive sampling merupakan salah satu bentuk dari convenience sampling yang dimana dalam teknik ini sampel dipilih berdasarkan penilaian atau pandangan dari para ahli berdasarkan tujuan dan maksud penelitian. Informan yang ingin dijadikan sebagai sampel adalah pegawai Kantor Kecamatan Mamasa dan masyarakat yang menjadi pengguna layanan, diantaranya adalah sebagai berikut:

Tabel 2. Informan Penelitian

\begin{tabular}{|l|l|lr|}
\hline No & \multicolumn{1}{|c|}{ Nama } & \multicolumn{1}{|c|}{ Jabatan / Pekerjaan } \\
\hline 1 & $\begin{array}{l}\text { Hesron } \\
\text { Lululangi, } \\
\text { S.Pt, MPd }\end{array}$ & Camat Kecamatan Mamasa \\
\hline 2 & $\begin{array}{l}\text { Jeim Respin } \\
\text { S.Stp, M.Si }\end{array}$ & Sekertaris Kecamatan \\
\hline 3 & $\begin{array}{l}\text { Abraham } \\
\text { Thung, S.IP }\end{array}$ & $\begin{array}{l}\text { Kepala Seksi Pemerintahan, } \\
\text { Ketentraman dan Ketertiban } \\
\text { umum }\end{array}$ \\
\hline 4 & Elis Samsuriati & $\begin{array}{l}\text { Kepala Seksi } \\
\text { Umum }\end{array}$ & Pelayanan \\
\hline 4 & Ronius & Pegawai Kecamatan Mamasa \\
\hline 5 & Syamsir & Pegawai Kecamatan Mamasa \\
\hline 6 & Elga & $\begin{array}{l}\text { Masyarakat } \\
\text { Layanan }\end{array}$ & Pengguna \\
\hline 7 & Nita & $\begin{array}{l}\text { Masyarakat } \\
\text { Layanan }\end{array}$ & Pengguna \\
\hline 8 & Karaeng & $\begin{array}{l}\text { Masyarakat } \\
\text { Layanan }\end{array}$ & Pengguna \\
\hline 9 & Amel & $\begin{array}{l}\text { Masyarakat } \\
\text { Layanan }\end{array}$ & Pengguna \\
\hline 10 & Yunus & $\begin{array}{l}\text { Masyarakat } \\
\text { Layanan }\end{array}$ & Pengguna \\
\hline 11 & Yosep & $\begin{array}{l}\text { Masyarakat } \\
\text { Layanan }\end{array}$ & Pengguna \\
\hline 12 & Irdan & $\begin{array}{l}\text { Masyarakat } \\
\text { Layanan }\end{array}$ & Pengguna \\
\hline
\end{tabular}

\section{Instrumen Penelitian}

Instrumen penelitian ini menggunakan metode deskriptif dengan pendekatan kualitatif. Hal ini di dasarkan pada kondisi dan konteks masalah yang dikaji, yaitu Kualitas Pelayanan Pegawai Pada Kantor Kecamata Mamasa Kabupaten Mamasa. Dalam hal ini penelitian akan berinteraksi secara langsung dengan informan penelitian. Untuk teknik penelitian yang digunakan untuk menggali data adalah Observasi, Wawancara, Dokumentasi. 


\section{Teknik Pengumpulan Data}

Teknik pengumpulan data merupakan langkah yang paling strategis dalam penelitian, karena tujuan utama dari penelitian adalah mendapatkan data (Sugiyono, 2007: 62). Teknik pengumpulan data yang digunakan dalam penelitian ini adalah:

1. Observasi

Observasi yaitu pengamatan secara langsung di lokasi penelitian guna memperoleh keterangan data yang lebih akurat mengenai hal-hal yang diteliti.

2. Wawancara

Wawancara yaitu suatu cara untuk mendapatkan dan mengumpulkan data melalui tanya jawab dan dialog atau diskusi dengan informan yang dianggap mengetahui banyak tentang obyek dan masalah penelitian.

3. Dokumentasi

Dokumentasi adalah pencatatan berbagai arsip dan dokumentasi yang ada hubungannya dengan penelitian.

\section{Teknik Analisis Data}

Dalam melakukan analisis data pada penelitian ini, peneliti mengacu pada tahapan teknik analisis data menurut Miles dan Huberman dalam Herdiansyah, Haris (2010: 164) yaitu:

1. Pengumpulan data.

Pada tahap ini peneliti melakukan proses pengumpulan data dengan menggunakan teknik pengumpulan data yang telah ditentukan sejak awal.

2. Reduksi data (Data reduction)

Data yang telah diseleksi akan diolah dengan cara mereview dan menyatukan serta memformulasikan data, sehingga data yang sama dari hasil interview dan data non interview dapat dikategorisasikan untuk memudahkan informasi dalam proses analisis data.

3. Penyajian data (Data display).

Proses penyajian data dilakukan melalui penyusunan dan pengkategorisasian data yang diperoleh dari pengolahan data, sehingga penyatuan data tersebut dihubungkan dengan pola yang terdapat pada hasil temuan di lapangan yang selanjutnya akan di analisa oleh peneliti dengan berdasarkan teori yang relevan.

4. Tahap penarikan kesimpulan dan verifikasi (Conclusion drawing and verification).

Langkah terakhir dalam analisis data kualitatif menurut Miles dan Huberman adalah penarikan kesimpulan dan verifikasi.

\section{HASIL DAN PEMBAHASAN}

\section{Gambaran Umum dan Lokasi Penelitian}

Kecamatan Mamasa adalah sebuah kecamatan yang juga sekaligus ibukota kabupaten Mamasa, Provinsi Sulawesi barat, yang mempunyai luas wilayah 250,07 Km2 dengan batas-batas Kecamatan sebagai berikut:

- Sebelah utara berbatasan dengan Kecamatan Kalukku, Kabupaten mamuju

- Sebelah timur berbatatan dengan Kecamatan Tabang

Sebelah selatan berbatasan dengan Kecamatan Tawalian
- Sebelah barat berbatasan dengan Kecamatan Bambang

Secara geogrfis Kecamatan Mamasa terletak pada posisi koordinat 119025'BT, dan 2050'LS . Posisi dan tinggi daratan rata-rata adalah 1.025-3.000 meter diatas permukaan laut.

Dengan status sebagai ibukota Kabupaten Mamasa, Kecamatan Mamasa menjadi pusat pemerintahan yang ditandai dengan kompleks perkantoran pemerintahan daerah termasuk Kantor Bupati dan Kantor DPRD. Kecamatan Mamasa terbagi atas 1 Kelurahan dan 11 Desa. Luas wilayah Kelurahan/Desa sebagai berikut :

Tabel 3. Luas Kelurahan dan Desa di Kecamatan Mamasa

\begin{tabular}{|l|l|l|}
\hline No & Kelurahan/Desa & $\begin{array}{l}\text { Luas wilayah } \\
\left(\mathrm{Km}^{2}\right)\end{array}$ \\
\hline 1 & Kelurahan Mamasa & 7,11 \\
\hline 2 & Desa Osango & 11,54 \\
\hline 3 & Desa Rambusaratu & 36.02 \\
\hline 4 & Desa Lambanan & 88,31 \\
\hline 5 & Desa Lembangna Salulo & 4,03 \\
\hline 6 & Desa Taupe & 22,94 \\
\hline 7 & Desa Buntubuda & 6,98 \\
\hline 8 & Desa Tondok Bakaru & 36 \\
\hline 9 & Desa Pebassian & 6,93 \\
\hline 10 & Desa Manbulilling & 16,08 \\
\hline 11 & Desa Bombong Lambe' & 10,15 \\
\hline 12 & Desa Bubun Batu & 3,98 \\
\hline
\end{tabular}

Sumber : Kantor Kecamatan Mamasa, 2019.

Susunan Organisasi Kantor Kacamatan Mamasa

1. Kepala Kantor Kecamatan/Camat

2. Sekretaris Kecamatan

3. Sub bagian umum dan keuangan

4. Sub bagian kepegawaian dan program

5. Seksi Pemerintahan, Ketentraman dan Ketertiban umum

6. Seksi Pemberdayaan Masyarakat Desa

7. Seksi Perekonomian dan Pembangunan

8. Seksi Kesejahteraan Sosial

9. Seksi Pelayanan Umum

Hasil Penelitian dan Pembahasan

Untuk mengetahui bagaimana kualitas pelayanan publik di Kantor Kecamatan Mamasa, peneliti menggunakan 5 dimensi kualitas pelayanan publik menurut Hardiansyah yaitu Wujud (Tangible), Kehandalan (Reliability), Tanggap (Responsiviness), Jaminan (Assurance) dan Empati (Emphaty) dengan indikator-indikator yang digunakan tiap dimensi yang akan diuraikan sebagai berikut :

\section{a. Dimensi Wujud}

Adapun untuk mengukur dimensi wujud (Tangible) dalam upaya mengetahui bagaimana kualitas pelayanan publik yang diberikan Kantor Kecamatan Mamasa dapat diukur dengan indikator penilaian sebagai berikut:

1. Penampilan pegawai dalam memberikan pelayanan publik

Berkaitan dengan penampilan pegawai dalam memberikan pelayanan di Kantor Kecamatan Mamasa sudah berpenampilan rapi dan menggunakan seragam yang sudah ditentukan. Hal ini sesuai dengan pernyataan Camat Mamasa Bapak Hesron Lululangi, S.Pt., M.Pd, yang mengatakan bahwa : 
"Penampilan tentulah berpengaruh dalam memberikan pelayanan, yang dilihat pertama kalikan sikap dan penampilan, makanya saya selalu sarankan agar selalu berpakaian rapi dan berpenampilan menarik bahkan ada aturan yang sudah tetapkan dari pemerintah kabupaten hari ini pakaian ini, hari menggunakan ini, agar terlihat tetap seragam dan memberi kesan enak dipandang mata” (Wawancara. 23 April 2021)

Pernyataan diatas tersebut didukung pendapat dari Sekertaris Kecamatan Bapak Jeim Resvin S.Stp., M.Si, yang mengatakan bahwa :

"terkait penampilan itu sangat berpengaruh makanya saya selalu ingatkan kepada pegawai untuk tetap berpenampilan sopan dalam memberikan pelayanan”(Wawancara. 23 April 2021)

Dari wawancara diatas terlihat penampilan menjadi salah satu yang mendapatkan perhatian karena dianggap sangat berpengaruh dalam proses memberikan pelayanan agar menimbulkan kesan yang baik kepada pengguna layanan.

2. Kenyamanan tempat melakukan pelayanan

Pelayanan pada Kantor Kecamatan Mamasa dinilai masih kurang, seperti yang diutarakan oleh salah satu masyarakat Ibu Nita, yang mengungkapkan bahwa :

"kondisi pelayanan di Kantor Kecamatan Mamasa masih sangat perlu dibenahi dan ditingkatkan lagi khususnya kebersihan lingkungan dan tata ruangan yang perlu dirapihkan lagi" (Wawancara. 24 April 2021)

Hal senada juga diungkapkan oleh masyarakat yang lain Bapak Yunus, pengguna layanan yang menyatakan bahwa “

"kadang berdiri menunggu gilirang karena tidak disediakan temapt duduk atau kursi, ruangan khusus pelayanan juga sangat sempit jadi terbatas orang yang berada didalam akhirnya banyak menunggu giliran diluar halaman kantor atau di parkiran" (Wawancara. 24 April 2021)

Dari hasil wawancara diatas dapat dikatakan bahwa kenyamanan tempat pelayanan yang diberikan Kantor Kecamatan Mamasa masih sangat kurang, terlihat dengan banyaknya keluhan masyarakat.

3. Kemudahan dalam proses pelayanan

Dari penelitian yang dilakukan, Kecamatan Mamasa sudah memberikan kemudahan bagi pengguna layanan yang datang mengurus keperluannya.

Seperti yang dikemukakan salah satu masyarakat pengguna layanan Ibu Elga, yang menyatakan bahwa:

"kami dilayanani dengan baik, diberikan kemudahan untuk mengurus keperluan kami, bahkan diberikan solusi terhadap apa yng harus kami lakukan"(Wawancara. 24 April 2021)

Pernyataan diatas didukung penjelasan Camat Mamasa Bapak Hesron Lululangi, S.Pt., M.Pd, yang menyatakan bahwa :

"kalau memberikan kemudahan dalam proses pelayanan, saya selaku pimpinan disini selalu memberikan arahan kepada para pegawai saya pegawai untuk selalu memberikan kemudahan kepada masyarakat yang melakukan proses pelayanan" (Wawancara. 23 April 2021)
Berdasarkan hasil wawancara diatas dapat dikatakan bahwa dimensi Wujud pada indikator kemudahan dalam proses pelayanan yang dilakukan Kantor Kecamatan Mamasa masih belum berjalan maksimal karena kemudahan yang dimaksud masih menyesuaikan situasi dan kondisi yang berlaku dan bukan sesuai pedoman mekanisme pelayanan yang ditetapkan.

4. Kedisiplinan pegawai dalam melakukan proses pelayanan

Disiplin menjadi persyaratan mutlak bagi pembentukan sikap, perilaku, dan tata kehidupan untuk membentuk suatu kepribadian pegawai yang bertanggung jawab dalam bekerja.

Berdasarkan hasil wawancara dengan salah satu masyarakat pengguna layanan Ibu Nita mengayatakan bahwa :

"pegawai sudah sangat disiplin dalam memberikan pelayanan kepada kami, terlihat dari pelayanan yang mereka lakukan sudah berjalan dengan baik, mereka sudah tepat waktu dan bertanggung jawab" (Wawancara. 24 April 2021)

Selanjutnya, masyarakat lain Ibu Amel, menambahkan bahwa :

"mengenai kedisiplinan pegawai, bisa dikatakan sudah baik. Dalam bekerja mereka sesuai waktu yang ditentukan, artinya mereka bertanggung jawab terhadap pekerjaan mereka termasuk mereka tetap memperhatikan aturan yang diberlakukan dalam proses pelayanan”(Wawancara. 24 April 2021)

Disiplin harus ditanamkan kepada penyedia layanan agar pengguna layanan puas dengan apa yang dikerjakan.

5. Penggunaan alat bantu dalam pelayanan

Alat bantu dalam pelaksanaan pelayanan sangat dibutuhkan agar kelancaran proses pelayanan. Alat bantu yang digunakan pegawai pelayanan di Kantor Kecamatan Mamasa dalam menyelesaikan tugasnya adalah komputer atau laptop, print atau alat cetak lainnya, kamera untuk pembuatan KTP atau untuk dokumentasi lainnya.

Seperti yang diungkapkan Kepala Seksi Pemerintahan, Ketentraman dan Ketertiban umum Bapak Abraham Thung, S.IP, menyatakan bahwa:

"alat bantu seperti komputer atau laptop, kamera untuk mengambil gambar KTP, itu sangat diperlukan pada saat melakukan proses pelayanan sehingga pelayanan dapat berjalan dengan baik" ( Wawancara. 23 April 2021)

Hal yang sama diungkapkan pegawai kantor Kecamatan Mamasa bagian pelayanan Bapak Ronius, yang menjelaskan bahwa:

"dengan adanya alat-alat seperti Komputer atau laptop, Kamera, termasuk print untuk berkas-berkas, pekerjaan menjadi mudah dan tidak terlalu kesulitan dalam melakukan proses pelayanan kepada masyarakat. Tidak seperti dulu, masyarakat harus keluar dulu untuk menfoto copy berkasnya, sekarang sudah bisa dilakukan disini. Karena inikan pekerjaan rumit dan tidak bisa selesai dengan cepat jika tidak menggunakan alat bantu" ( Wawancara. 23 April 2021)

Dengan adanya alat bantu tersebut, pekerjaan petugas pelayanan publik menjadi lebih mudah seperti ketika melakukan penginputan data-data, 
print berkas maupun pengambilan gambar untuk pembuatan KTP. Namun tidak meratanya kemampuan pegawai menjadi masalah karena penggunaan atau pengoperasian alat bantu hanya di miliki beberapa pegawai saja.

Berdasarkan hasil pembahasan diatas maka dapat disimpulkan bahwa pelayanan publik di Kecamatan Mamasa sudah menerapkan dimensi Wujud (Tangibel) beserta indikatornya.

\section{b. Dimensi Kehandalam (Reliablity)}

Untuk mengukur dimensi kehandalan (Reliability) yang diterapkan oleh Kantor Kecamatan Mamasa sebagai penyedia layanan dalam upaya untuk mengetahui kualitas pelayanan publik di Kantor Kecamatan Mamasa, bisa dilihat dengan indikator penilaian sebagai berikut:

1. Kecermatan pegawai dalam melayani pengguna layanan

Berdasarkan hasil penelitian yang dilakukan, petugas pelayanan Kantor Kecamatan Mamasa sudah dinilai cermat atau teliti dalam memberikan pelayanan kepada masyarakat seperti yang dikatakan salah satu masyarakat pengguna layanan Ibu Elga yang mengungkapkan bahwa :

"iya, selama proses pelayanan saya melihat pegawai kecamatan yang bertugas melayanai kami itu sudah cermat dalam melayani, seandainya ada kesalahanpun itu tidak menonjol karena tidak terlihat dan merugikan kami”(Wawancara. 24 April 2021)

Pernyataan diatas diperkuat Sekertaris Kecamatan Bapak Jeim Resvin, S.Stp., M.Si, yang menyatakan bahwa :

"petugas pelayanan sudah cermat dalam melakukan tugasnya, terbukti kami belum pernah menerima komplen dari masyarakat terkait apa yang mereka urus karena tidak sesuai datanya. Pegawai semaksimal mungkin menggunakan cara agar lebih baik dalam melayani"(Wawancara. 23 April 2021)

Dari hasil wawancara terkait kecermatan petugas dalam memberikan layanan maka dapat disimpulkan bahwa pegawai petugas pelayanan Kantor Kecamatan Mamasa telah cukup cermat dalam melayani pengguna layanan.

2. Memiliki Standar Pelayanan yang jelas

Standar pelayanan akan mempermudah alur proses pelayanan. Kecamatan Mamasa telah memiliki Standar Operasional Prosedur, SOP inilah yang digunakan dalam memberikan pelayanan kepada masyarakat.

Seperti yang diungkapkan Camat Mamasa Bapak Hesron Lululangi, S.Pt., M.Pd, yang menyatakan bahwa :

"kami memiliki Standar Operasioal Prosedur, inilah yang menjadi pedoman pegawai kami dalam melayani asyarakat"(Wawancara 23 April 2021)

Pernyataan tersebut dibenarkan Kepala Seksi Pelayanan Umum Ibu Elis Samsuriati, yang menjelaskan bahwa:

"iya ada SOP, SOP inilah yang mengarahan petugas kami melaksakan tugas-tugasnya seperti bagaimana alur pelayanan, berapa biayanya jika memang ada dan lain-lain" (Wawancara 23 April 2021)

Dari pendapat-pendapat diatas diketahui bahwa Kantor Kecamatan Mamasa menggunakan Standar pelayanan berbentuk Standar Operasional Prosedur dalam memberikan layanan kepada masyarakat hanya saja SOP ini tidak diketahui ole masyarakat.

3. Kemampuan Pegawai dalam menggunakan alat bantu dalam proses pelayanan

Keahlian atau Kemampuan pegawai menggunakan alat bantu dalam proses pelayanan adalah modal dasar dalam menunjang peningkatan kualitas pelayanan.

Hal ini diungkapkan oleh Kepala Seksi Pemerintahan, Ketentraman dan Ketertiban umum Bapak Abrahaman Thung, S.IP, yang menyatakan bahwa :

"kemampuan pegawai dalam menggunakan alat bantu sudah sangat mahir dan dapat diandalkan dalam memberikan pelayanan" (Wawancara 23 April 2021)

Pernyataan tersebut diatas selaras dengan pendapat Sekertaris Kecamatan Bapak Jeim Resvin, S.Stp., M.si, yang menjelaskan bahwa :

"petugas kami sangat mampu menggunakan alat bantu tersebut. Mereka sudah sangat bisa diandalkan terutama pegawai baru mereka sudah terbiasa menggunakan alat-alat tersebut" (Wawancara 23 April 2021)

Namun, berdasarkan penelusuran peneliti, pegawai pelayanan yang ada di Kecamatan Mamasa belum semuanya mampu untuk menggunakan alat bantu yang ada di ruang pelayanan.

\section{c. Dimensi Daya Tanggap (Responsiviness)}

Untuk mengukur kualitas kinerja pelayanan yang diberikan Kantor Kecamatan Mamasa selanjutnya adalah dengan menggunakan dimensi daya tanggap atau Responsiviness. Upaya untuk mengetahui sejauhmana kualitas pelayanan publik yang diberikan oleh di Kantor Kecamatan Mamasa pada dimensi daya tanggap ini dapat diukur melalui beberapa indikator sebagai berikut:

1. Merespon setiap pengguna layanan yang ingin mendapatkan pelayanan.

Petugas pelayanan wajib memberikan tanggapan atau merespon masyarakat yang datang untuk mengguna layanan dalam memenuhi kebutuhannya.

Dengan memberikan tanggapan atau respon yang baik akan membuat pengguna layanan pasti merasa senang. Ini akan menjadi penilaian yang positf untuk penyedia layanan.

2. Pegawai melakukan pelayanan dengan cepat dan tepat

Ketika petugas pelayanan memberikan layanan dengan proses yang cepat dan tepat akan membuat pengguna layanan akan merasa puas dan senang.

Seperti yang dijelaskan oleh pengguna layanan Ibu Amel, yang menyatakan bahwa :

"cepat dan tepatnya itu sepertinya tidak pasti, waktu saya pergi mengurus pelayanannya cepat dan sudah maksimal, saya hanya menunggu sebentar. Tapi keluarga saya yang pernah kesana, cerita katanya lama menunggu baru jadi, apalagi sekarang dengan adanya corona jadi yang dilayanai dibatasi, kita harus cepat ke kantor kecamatan ambil antrian kalau mau dilayanai hari itu juga" (Wawancara 23 April 2021)

Berdasarkan wawancara diatas maka diketahui bahwa tidak semua pegawai dapat melayani dengan 
cepat. Semua itu tergantung pada siapa pegawai yang bertugas. Jika banyak yang mengantri maka kemungkinan untuk melayani dengan cepat tidak bisa dilakukan, apalagi dengan adanya Covid 19, pelayanan menjadi berbeda dengan sebelumnya.

Hal ini diungkapkan Kepala Seksi Pemerintahan, Ketentraman dan Ketertiban umum Bapak Abraham Thung, S.IP, yang menyatakan bahwa :

"kalau dibilang cepat dan tepat sebenarnya masih kurang karena terkadang pegawai datang tidak tepat waktu dalam melakukan pelayanan, ada beberapa pegawai yang juga sering terlambat masuk" (Wawancara 23 April 2021)

3. Semua keluhan pelanggan direspon oleh pegawai

Keluhan dari masyarakat akan muncul jika petugas layanan tidak melaksanakan tugasnya dengan baik. Untuk merespon keluhan, Kecamatan Mamasa menyediakan sarana untuk menyampaikan terkait proses pelayanan yaitu berupa kotak saran untuk menyampaikan keluhan maupun memberi masukan.

Seperti yang dikatakan Camat Mamasa Bapak Hesron Lululangi, S.Pt. M.Pd, yang menjelaskan bahwa :

"untuk persolan yang bisa diselesaikan dengan cepat, pegawai kami akan langsung merespon dengan cepat namun ada juga yang memerlukan waktu untuk menyelesaikannya"(Wawancara 23 April 2021)

Lebih lanjut Camat Mamasa Bapak Hesron Lululangi, S.Pt. M.Pd, mmenyatakan bahwa :

"keluhan yang paling ada sekarang ya keluhan karena adanya Corona itu, karena kita batasi beberapa jumlahnya yang dilayani setiap hari. Saat ini solusi untuk mengatasi Corona ini, kita hanya mengikuti instruksi dari Pemerintah pusat dan Daerah"(Wawancara 23 April 2021)

Hasil penelitian menunjukkan bahwa pelayanan Kantor Kecamatan Mamasa dalam menerima pengaduan atau keluhan dari masyarakat telah dilaksanakan.

\section{d. Dimensi Jaminan (Assurance)}

Dimensi Jaminan (Assurance) adalah pengetahuan, kemampuan, kesopanan dan sifat dapat dipercaya yang dimiliki oleh pegawai, bebas dari bahaya, resiko, dan keragu-raguan.

Sementara untuk mengukur dimensi Jaminan atau Assurance dalam upaya mengetahui tingkat kualitas pelayanan publik diberikan Kantor Kecamatan Mamasa dapat diukur melalui indikator sebagai berikut :

1. Petugas memberikan jaminan tepat waktu dalam pelayanan

Untuk mengukur kualitas pelayanan yang diberikan salah satunya adalah jaminan tepat waktu.

Seperti yang jelaskan Camat Mamasa Bapak Hesron Lululangi, S.Pt. M.Pd, yang mengatakan bahwa:

"tentu saja ada, kami kan ada SOP. Disitu diatur tentang proses pelayanan, waktu pelayanan dan seterusnya. Jadi jaminan penyelesaian tetap kami berikan kepada masyarakat. Apabila yang diurus masyarakat bisa diselesaikan satu hari maka akan diselesaikan saat itu juga tapi jika pengurusan tersebut membutuhkan beberapa hari maka kami akan meminta masyarakat kembali tapi tetap ada waktunya yang kami berikan kepada masyarakat tentang penyelesaian apa yang mereka urus tersebut" (23 April 2021)

Pelayanan publik memang harus memberikan jaminan tepat waktu kepada pengguna layanan agar pengguna layanan punya kepastian waktu penyelesaian kebutuhan mereka.

2. Petugas memberikan jaminan biaya dalam pelayanan

Mengurus keperluan di Kantor Kecamatan Mamasa tidak semua menggunakan biaya untuk mengurusnya. Hanya untuk hal-hal tertentu saja seperti mengurus IMB Sebagaimana yang dikemukakan oleh pegawai kecamatan Bapak Ronius, yang menyatakan bahwa :

"mengenai biaya dalam memberikan pelayanan tidak ada, pelayanan dilakukan tanpa dipungut biaya" (Wawancara 23 April 2021)

Pendapat diatas didukung pernyataan Camat Mamasa Bapak Hesron Lululangi, S.Pt. M.Pd, yang menjelaskan bahwa:

"soal biaya pelayanan tidak ada, pelaksanaan pelayanannya tidak dipungut biaya sedikitpun" (Wawancara 23 April 2021)

Dengan adanya jaminan biaya dari pegawai pelayanan, maka pengguna layanan tidak perlu mengeluarkan uang untuk mengurus keperluannya.

Berdasarkan hasil penelitian dapat disimpulkan bahwa pelayanan publik yang dilakukan Kecamatan Mamasa, dianggap sudah menerapkan dimensi Jaminan atau Assurance berserta indikatornya.

e. Dimensi Empati (Emphaty)

Dimensi Empati (Emphaty) meliputi kemudahan dalam melakukan hubungan, komunikasi yang baik dan memahami kebutuhan pengguna layanan.

Untuk mengukur dimensi Empati (Emphaty) Kantor Kecamata Mamasa dalam upaya mengetahui tingkat kualitas pelayanan publik yang diberikan di dapat diketahui melalui indikator sebagai berikut :

1. Mendahulukan Kepentingan pengguna layanan

Sebagaimana yang dikatakan Sekertaris Kecamatan Bapak Jeim Resvin, S.Stp., M.Si, yang menerangkan bahwa:

"dalam hal ini, pegawai lebih mementingkan kepentingan pengguna layanan daripada kepentingn pribadi mereka. Apalagi kami awasi pekerjaan mereka. (Wawancara 23 April 2021)

Akan tetapi ketika peneliti mengamati proses pelayanan tidak semua petugas pelayanan mendahulukan kepentingan pengguna layanan. Seperti terlihat ketika pengguna layanan masih ada yang mengantri namun ada pegawai yang ditemukan memilih untuk mementingkan urusan pribadinya seperti menerima telpon berlama-lama, pergi keluar dari kantor untuk urusan pribanya dan lain sebagainya.

Hal tersebut sesuai dengan hasil wawancara dengan salah satu Masyarakat Bapak Yakup, pengguna layanan yang mengatakan bahwa :

"biasa mereka menerima telpon berlama-lama, meskipun tetap bekerja karena memakai headset tapi tetap saja membuat mereka tidak fokus sehingga lambat proses penyelesaiannya, ada juga sering keluar masuk tidak jelas apa yang diurus" (Wawancara 24 April 2021) 
Memberikan prioritas utama kepada pengguna layanan memang penting karena jika pengguna layanan tidak merasa didahulukan akan timbul keluhan dan tentu memberikan citra yang buruk bagi bagian pelayanan.

2. Petugas melayani dengan ramah dan sopan santun

Dalam memberikan pelayanan, keramahan pegawai pelayanan sangat diperlukan.

Seperti yang dijelaskan Camat Mamasa Bapak Herson Lululangi, S.Pt., M.Pd, yang menyatakan bahwa :

"terkait masalah kesopanan, tentu diterapkan bukan hanya kepada yang dikenal saja tetapi kepada semua pengguna layanan. Namun perlu ditingkatkan lagi adalah keramahannya" (Wawancara 23 April 2021)

Pendapat diatas berbeda dengan salah satu masyarakat pengguna layanan Ibu Elga, yang mengatakan bahwa:

"tidak semuanya ramah dan sopan, ada yang sopan dan ramah tapi ada juga yang tidak, ada yang banyak diam kadang hanya bicara sesekali bahkan perna saya tanya hanya menjawab seadanya" (Wawancara 24 April 2021)

Keramahan dan sikap sopan santun memang sangat penting dimiliki oleh pegawai pelayanan dalam memberikan pelayanan, jika pegawai layanan ramah dan sopan maka hubungan dan komunikasi akan lebih aktif antara pemberi layanan dengan pengguna layanan dan pengguna layanan akan merasa nyaman dan puas.

3. Pegawai melayani dengan tidak diskriminatif (Membeda-bedakan)

Selain keramahan dan sikap sopan santun, sikap tidak diskriminatif atau sikap tidak membedabedakan juga sangat perlu untuk diterapkan dalam proses pelayanan.

Dalam hal ini Sekertaris Kecamatan Bapak Jeim Resvim, S.Stp., M.Si, mengatakan bahwa:

"tidak ada seperti itu, pegawai mengikuti aturan yang berlaku, tidak membeda-bedakan pengguna layanan yang satu dengan lainnya. Semua diperlakukan sama”(Wawancara 23 April 2021)

Berbeda dengan pendapat diatas, Kepala Seksi Pemerintahan, Ketentraman dan Ketertiban umum Bapak Abraham Thung, S.IP, mengungkapkan bahwa:

"walaupun selalu diinstruksikan untuk tidak membeda-bedakan namun kalau ada keluarga pegawai yang datang terkadang didahulukan dari pengguna layanan yang tidak memiliki keluarga pegawai disini" (Wawancara 23 April 2021)

Berdasarkan Wawancara diatas, ditemukan ketidak sepahaman sesama pegawai kantor Kecamatan Mamasa dalam memberikan informasi.

4. Pegawai melayani dan menghargai setiap pengguna layanan

Sikap menghargai harus dimiliki oleh semua petugas pelayanan, dengan menghargai maka akan meningkatkan kualitas pelayanan.

Seperti yang dikatakan Sekertaris Kecamatan Bapak Jeim Resvim, S.Stp., M.Si, yang menyatakan bahwa :

"pegawai kami sudah melayanai dengan sebaikbaiknya, mereka menghargai setiap masyarakat yang datang mengurus keperluannya seperti mendengarkan dengan baik ketika masyarakat berbicara menyampaikan keperluannya ataupun keluhannya"(Wawancara 23 April 2021)

Berdasarkan hasil penelitian maka dapat disimpulkan bahwa pelayanan publik di Kecamatan Mamasa sudah menerapkan dimensi Empati (Emphaty) berserta indikatornya.

\section{SIMPULAN}

Berdasarkan uraian pada hasil penelitian dan pembahasan, dapat ditarik kesimpulan bahwa Kualitas pelayanan publik di Kantor Kecamatan Mamasa Kabupaten Mamasa sudah menerapkan dimensi Bukti Fisik/wujud, Kehandalan, Daya Tanggap, Jaminan, Empati beserta indikatornya dalam memberikan Pelayanan sudah berjalan baik. Namun masih ada beberapa indikator yang belum berjalan sesuai dengan keinginan masyarakat, antara lain ketidak nyamanan tempat pelayanan termasuk sarana dan prasarana yang belum lengkap, belum semua pegawai mampu dan ahlinya dalam menggunakan alat bantu pelayanan, dan ketidak ramahan pegawai dalam proses pelayanan, waktu proses yang tidak pasti atau lama dan adanya pegawai yang mendahulukan kepentingan pribadi daripada kepentingan umum serta membeda-bedakan dalam memberikan pelayanan.

\section{DAFTAR PUSTAKA}

Agusnadi, A. (2014). Efektivitas Pemberian Sanksi Bagi Siswa Pada Pelanggaran Tata Tertib Di Smp 2 Kapuas Timur Kabupaten Kapuas. Jurnal Pendidikan Kewarganegaraan, $4(8), 121400$

Abdullah, M. 2014. Manajemen dan Evaluasi Kinerja Karyawan. Yogyakarta : Penerbit Aswaja Pressindo.

Amirullah. (2015). Populasi dan Sampel. 1-14. https://doi.org/10.1007/BF00353157

Hardiyansyah. 2011. Kualitas Pelayanan Publik Konsep, Dimensi, Indikator dan Implementasinya. Yogyakarta : Gava Media.

Heriawan, S. (2016). Pola Komunikasi Kelompok Pada Komunitas Scooter "Vespa" Dalam Menjalin Hubungan Solidaritas (Studi Deskriptif Kualitatif Pada Komunitas Ikatan Scooter Wonogiri di Wonogiri) NASKAH. Naskah Publikasi, 53(9), 12.

Moenir. 2015. Manajemen Pelayanan Umum Di Indonesia.Cetakan Kesebelas. Jakarta: Bumi Aksar, Hlm 16-17.

Nurfitrah, 2019 Faktor Instrinsik Motivasi Kerja Pegawai Dalam Meningkatkan Pelayanan Administrasi Di Kantor Kecamatan Malunda Kabupaten Majene, Mitzal (Demokrasi, Komunikasi Dan Budaya): Jurnal IImu Pemerintahan Dan IImu Komunikasi.

Herdiansyah, Haris. 2010. Metode Penelitian Kualitatif untuk IImu-ilmu Sosial. Jakarta: Salemba Humanika.

Sugiyono. 2007. Metode Penelitian Kuantitatif Kualitatif dan R\&D. Bandung: Alfabeta.

Wirawan. (2015). Manajemen Sumber Daya Manusia Indonesia. Jakarta: PT Raja Grafindo Persada.

Hasil Wawancara

Wawancara, 23 April 2021 - Wawancara, 24 April 2021

Perundang - undangan

Peraturan Menteri Pendayagunaan Aparatur Negara Dan Reformasi Birokrasi Republik Indonesia Nomor 15 Tahun 2014 